\title{
GOTAS DE SANGUE
}

Milena Silva Pinheiro ${ }^{1}$

Em meados de abril, os botões polvilham os ramos, como se fossem flocos de neve vermelhos. O Samurai saiu para a luta, com sua armadura de benevolência e sua espada forjada de perseverança.

Deparou-se com uma velha e enorme cerejeira. Atraído por sua beleza, tocou delicadamente os botões da árvore e beijou suas dores. Os gomos sentiam dor ao crescerem e então, davam à luz as folhas e flores. Na chuva, imaginava os botões chorando de dor, mas depois, a alegria de quando a flor desabrochasse.

Fica sobre as cerejeiras, enquanto as flores se dirigem ao chão, que the recebe tão carinhosamente, como um pedaço de seu amor. O samurai estende sua mão para a flor, que conhece o coração enevoado do rei. Pensa ele, que a árvore se preparou durante muito tempo para mostrar ao mundo suas flores, mas vivem apenas três dias.

O guerreiro reconhece a bravura da cerejeira para manter as flores vivas, tempo insuficiente para tamanha grandeza, pois ele queria que o seu reinado continuasse por 8 mil anos, até os seixos crescerem nos penhascos cobertos de musgos verdes claros.

Nesse intervalo de tempo, uma flor única cai sobre a água e fica à deriva. O Samurai olha para o espelho d'água e vê seu rosto marcado por lutas passadas, o olhar perdendo a vida, mas o brilho ainda permanecia lá. Flor de cerejeira pra longe vai voar, nem mesmo sua voz vai poder alcançar. Dor de botões de árvore, nascendo em flores, pétalas caem, gotas de sangue. O vento sopra, assim como a flor, o Samurai se vai.

\footnotetext{
${ }^{1}$ Estudante da $3^{a}$ série do Ensino Médio do Colégio São Francisco de Sales, Diocesano (Teresina-PI). E-mail: milenapinheiro1771@gmail.com
} 